\title{
Classification of gastrointestinal stromal tumor syndromes
}

\author{
Priya Gopie1,*, Lin Mei1,*, Anthony C Faber ${ }^{2}$, Steven R Grossman', Steven C Smith ${ }^{3}$ and Sosipatros A Boikos' \\ 1 Massey Cancer Center, VCU School of Medicine, Virginia Commonwealth University, Richmond, Virginia, USA \\ 2Phillips Institute for Oral Health Research, VCU School of Dentistry and Massey Cancer Center, Virginia Commonwealth University, Richmond, \\ Virginia, USA \\ 3Departments of Pathology and Surgery, VCU School of Medicine, Virginia Commonwealth University, Richmond, Virginia, USA \\ Correspondence should be addressed to S Boikos: sosipatros.boikos@vcuhealth.org \\ *(P Gopie and L Mei contributed equally to this work)
}

\begin{abstract}
Gastrointestinal stromal tumors (GISTs) are the most common mesenchymal tumors of the gastrointestinal tract, thought to derive from neoplastic outgrowth of the interstitial cells of Cajal. Building on recent advances in recognition, classification and diagnosis, the past two decades have seen a changing paradigm with molecular diagnostics and targeted therapies. KIT and PDGFRA mutations account for $85-90 \%$ of GIST carcinogenesis. However, the remaining $10-15 \%$ of GISTs, which until recently were called KITIPDGFRA wild-type GISTs, have been found to have one of the several mutations, including in the SDHA, B, C, D, BRAF and NF1 genes. Though most of such GISTs are sporadic, a number of families with high incidence rates of GISTs and other associated clinical manifestations have been reported and found to harbor germline mutations in $K I T, P D G F R A, S D H$ subunits and NF1. The goal of this review is to describe the mutations, clinical manifestations and therapeutic implications of syndromic and inherited GISTs in light of recent studies of their clinicopathologic range and pathogenesis.
\end{abstract}

\author{
Key Words \\ - GIST \\ - imatinib \\ - KIT \\ - PDGFRA \\ - NF1 \\ - $S D H x$
}

\section{Introduction}

Gastrointestinal stromal tumors (GISTs) are the most common mesenchymal tumors of the gastrointestinal (GI) system (Boikos \& Stratakis 2014), with more than 5000 newly diagnosed cases yearly in the United States (Barnett et al. 2013). The incidence of these tumors is variable from as low as 4.3-6.8 per million to as high as 19-22 cases per million, with a high degree of variability between different geographic areas (Soreide et al. 2016). The reported median age is in the mid-60s in most studies (Soreide et al. 2016); the stomach is the most frequent primary site, involving $\sim 55 \%$, followed by small intestine $(\sim 30 \%)$ and rectum ( 5\%) (Barnett et al. 2013, Soreide et al. 2016). Rarely, GISTs arise in other GI locations or appear clinically to arise as primary tumors in other viscera.

Historically, smooth muscle was considered the tissue of origin of GISTs, given the predominant spindle cell histomorphology and frequent expression of smooth muscle cell markers (Schroeder et al. 2016). In the late 1990s, a key finding in GISTs was the discovery of their similarity to the interstitial cells of Cajal, specialized stromal cells which serve as the pacemaker for the GI tract by integrating neurotransmitter and other signals to coordinate smooth muscle cell contractions. c-KIT protein (also known as CD117), which is commonly expressed both on interstitial cells of Cajal and GISTs, is a crucial 
driver of tumor growth (Hirota et al. 1998, Kindblom et al. 1998). The KIT gain-of-function mutation is well established as the molecular driver of a majority of GISTs, while expression of the c-KIT protein provides a standard of care diagnostic marker (Hirota et al. 2000). Besides KIT mutations, GISTs have been found to harbor mutations in other genes, including platelet-derived growth factor (PDGF) receptor alpha (PDGFRA), succinate dehydrogenase complex subunits $(S D H x)$, neurofibromin 1 (NF1), B-raf proto-oncogene $(B R A F)$ and most recently, epigenetic changes 'epimutation' of SDHC. An even smaller subset of until recently unclassified GISTs is now known to harbor even rarer mutations, including PI3K3CA, CBL and KRAS.

Most of the GISTs are sporadic, but in approximately $5 \%$ of the patients, GIST is part of one of several familial syndromes. These syndromes include Carney-Stratakis syndrome (CSS), Carney triad, neurofibromatosis type 1 and primary familial GIST syndrome (Carney \& Stratakis 2002, Mussi et al. 2008, Agarwal \& Robson 2009, Forde et al. 2016). Recently, it had been shown that CSS and Carney triad are characterized by mutations and methylation changes, respectively, of $S D H$ subunit genes, leading to global SDH deficiency, while neurofibromatosis-associated and familial GIST syndrome tumors remain SDH-competent.

These rare hereditary GISTs, several having distinctive clinical features and characteristic genomic alterations only well appreciated in recent years, are the subject of this review. From the standpoint of organization, in this review, discussion of GIST syndromes will be organized along the two aforementioned overall molecular classes of GISTs (SDH-competent and SDH-deficient). While these two molecular groups are often used to describe GISTs generally (irrespective of whether they have documented syndromic features or germline mutation), they importantly correspond to groups that may have specific, targetable oncogenic mutations, especially among the SDH-competent GISTs. While in contrast, the emerging group of SDH-deficient GISTs presently has less clear targeted therapies, they imply specific surveillance recommendations and differing treatment pathways, emphasizing that a precision medicine approach is standard of care even among different groups of syndromal GISTs.

\section{SDH-competent familial GISTs (mutations in KIT, PDGFRA or NF1)}

\section{KIT-mutated syndromic GISTs}

The landmark discovery of activating mutations of c-KIT in GISTs was reported in 1998 (Hirota et al. 1998). It is now well established that $75 \%$ of the GISTs harbor KIT mutations, and subsequent pharmacologic findings have proven that it is a clinically important therapeutic target. KIT encodes the c-KIT receptor tyrosine kinase, a type III tyrosine kinase receptor, which is the receptor of stem cell factor (SCF). The binding of SCF ligand induces c-KIT dimerization, which induces receptor activation and downstream signaling mobilization, including through the PI3K/AKT and RAS pathways (Bauer et al. 2007). Contemporary understanding of the molecular pathogenesis of GISTs underscores that KIT mutation and its dependent signaling pathways are the hallmark of GISTs and distinct from other sarcoma types.

Beyond the vastly more common sporadic GISTs with somatic mutation of KIT, recent studies have established that rare familial GIST cases are related to heritable germline mutations of KIT (Forde et al. 2016). In fact, to date more than 31 families and 6 individuals have been found to have germline mutations in KIT, most often in exon 11 but also in exons 8, 9, 13 and 17 (Ricci 2016). Consistent with its oncogenic function, the inheritance pattern in these families is autosomal-dominant, and the youngest reported age of GIST diagnosis is 15 , with median age of $40-50$ ( $\mathrm{Li}$ et al. 2005, Kleinbaum et al. 2008). These families have often other clinical manifestations, including achalasia, melanoma, multiple lentigines, perioral and perineal hyperpigmentation and urticaria pigmentosa. GISTs in these patients tend to have spindle cell histology and can be seen anywhere in the GI tract, including the esophagus, stomach and small bowel. KIT-mutated GISTs (whether somatic or germline) tend not to metastasize to lymph nodes. There are neither major differences as compared to sporadic KIT-mutated GISTs in terms of medical and surgical treatments, nor a clear female predominance. However, consistent with the presence of constitutional (germline) KIT mutations being present in every cell, affected individuals demonstrate diffuse hyperplasia of their interstitial cells of Cajal. This is a unique feature, contrasting the other germline mutations associated with GIST development, and providing supportive evidence of the defining role of c-KIT activation in the hereditary and sporadic settings.

Two years after the discovery of activating KIT mutation in GISTs, imatinib was identified as a potent antagonist of c-KIT in the cellular model (Heinrich et al. 2000). Only one year after this in vitro study, a favorable outcome was reported in a case report (Joensuu et al. 2001). Not surprisingly, the subsequent large cohort clinical trial achieved great success by using imatinib 
(Demetri et al. 2002). In familial KIT-mutated GISTs, response to imatinib can be variable, based on the specific tumor genotype.

\section{PDGFRA-mutated syndromic GISTs}

Of sporadic GISTs that do not harbor somatic KIT mutations, PDGFRA is the most common oncogenic mutation. PDGFRA is a type III tyrosine kinase receptor, a close homolog of c-KIT, functioning physiologically as the receptor of several PDGF isoforms (Joensuu \& DeMatteo 2012). PDGFRA mutation induces constitutive kinase activation and interacts with c-KIT. Consistent with their functional overlap, these mutations are mutually exclusive in GISTs (Heinrich et al. 2003b, Hirota et al. 2003, Corless et al. 2011). Quite analogous to the aforementioned observation of kindreds with germline KIT mutation and predisposition to GISTs, recently a rare, familial counterpart of sporadic PDGFRA-mutant GISTs has been identified (Ricci et al. 2015). Three families and one individual have been described harboring germline PDGFRA mutations; the clinical manifestations in these families are variable, including lipomas, fibrous tumors in the GI tract and large hands (Chompret et al. 2004, Pasini et al. 2007, Carney \& Stratakis 2008).

Overall, PDGFRA mutations in GISTs cluster in exons 12 (juxtamembrane regulatory domain), 14 (tyrosine kinase domains-ATP-binding region) and 18 (activation loop). Interestingly, PDGFRA-mutant GISTs have mostly epithelioid histology; they arise primarily in the stomach. Usually, patients with PDGFRA-mutated GISTs tend not to have metastases to lymph nodes. Specifically in PDGFRAmutant syndromal GISTs, there is a strong female predominance (Ricci 2016). Contrasting somewhat the finding in kindreds affected by germline KIT mutation, patients with PDGFRA germline mutations never have diffuse hyperplasia of interstitial cells of Cajal, instead of having only focal hyperplasia (Chompret et al. 2004).

Beyond the rare scenario of PDGFRA mutation-related hereditary GISTs, in PDGFRA-mutated GISTs generally, the mutation type is associated with important clinical and therapeutic outcomes. Mutations in exons 12, 14 and 18 demonstrate variable response to imatinib, sunitib and regorafenib (Jakhetiya et al. 2016). Most of the PDGFRA mutations have been identified in exon 18, which is believed to stabilize the kinase activation loop (Dibb et al. 2004). The most frequent single mutation, the PDGFRA mutation, c. $2525 A>T$ causing the amino acid substitution D824V, occurs in $70 \%$ of all PDGFRA mutations and 5\% of metastatic GISTs (Corless et al. 2005). It is considered as the most common mutation conveying primary resistance to imatinib (Heinrich et al. 2003a), and median survival is only 12.8 months compared with 48-60 months on average for imatinib-treated GISTs (Corless et al. 2011). Due to this primary resistance to imatinib or sunitinib, alternative approaches, including dasatinib or crenolanib, have been used and are thought to have greater activity (Heinrich et al. 2012). Fortunately, the PDGFRA mutation, c.2525A>T, despite being the most common PDGFRA mutation in sporadic GISTs, has never been reported in the germline mutants.

\section{Neurofibromatosis type 1 (NF-1)}

NF-1 is an autosomal-dominant tumor syndrome that is caused by mutation of the NF1 gene located on chromosome 17 . It is characterized by café-au-lait spots, neurofibromas, pheochromocytoma and in some cases, GISTs. NF-1 is relatively common, with 1:4-5000 prevalence, and has complete penetrance but variable expression in terms of its broad clinical manifestations. Approximately 7\% of the patients develop a GIST during their lifetime (Zoller et al. 1997). The median age of GIST diagnosis in NF-1 patients is 49. NF-1-related GISTs are located in the small bowel, are often multifocal, have a spindle cell morphology and often a background of Cajal cell hyperplasia (Wada et al. 2016). NF-1 patients can also have other GI tumors like neuroendocrine tumors (including somatostatinomas arising from the ampulla). NF-1 syndromal GISTs are usually small with a low mitotic rate and generally good prognosis, though $15-20 \%$ of the NF-1-related GISTs can be aggressive (Wang et al. 2011). There is no clear female predominance in these patients. From a therapeutic standpoint, NF-1-related GISTs have not responded well to imatinib (Mussi et al. 2008). While there is no reported efficacy of imatinib, there is a report of a response to sunitinib (Kalender et al. 2007). Currently, there is an ongoing trial at the US National Institutes of Health designed to target NF-1-related GISTs through MEK inhibition (NCT03109301).

The prognosis of NF-1-associated GISTs is controversial. In one cohort, reported by Miettinen et al., these patients enjoyed an overall good prognosis, with only five out of 35 patients dying of metastatic disease (Miettinen et al. 2006). Conversely, two case reports have stated that NF-1-mutated GISTs either only showed an initial response to imatinib (Lee et al. 2006) or were completely resistant to imatinib (Mussi et al. 2008). Of note, these studies have substantial discrepancy of tumor-proliferative status, mitotic count and tumor size, which may explain the 
different outcomes. We emphasize that greater experience will be necessary in this area, and the role of adjuvant treatment with imatinib in NF-1 syndromal cases remains debatable (Mussi et al. 2008).

\section{SDH-deficient GISTs (SDHA, B, C, D mutations, SDHC epimutants)}

\section{The SDH complex}

The succinate dehydrogenase (SDH) complex, also known as complex II, is a heterotetrameric enzymatic complex composed of A, B, C and D subunits, located in the inner mitochondrial membrane (Gill 2012). The SDH complex physiologically plays a role in both the Krebs cycle and the respiratory chain. Mutation in any of the subunits leads to instability of the complex and degradation of SDHB subunit protein. For that reason, loss of SDHB expression, as detected by immunohistochemistry (IHC), is being increasingly used as a marker for the SDHdeficient phenotype, which can subsequently be clarified by genetic studies (Gill et al. 2010). SDH deficiency leads to intracellular succinate accumulation, which inhibits a broad family of enzymes that are called dioxygenases, including propyl-hydroxylases, JmjC domain-containing histone demethylases (KDMs) and the TET family of dioxygenases (Killian et al. 2013, Boikos et al. 2014, Wang et al. 2015) (Fig. 1). Inhibition of prolyl-hydroxylases leads to hypoxia-inducible factor (HIF) 1a stabilization, inducing constitutive pseudohypoxic signaling and consequent upregulation of expression of several oncogenes. Inhibition of TET and KDM family enzymes leads to DNA and histone hypermethylation, respectively (Yang \& Pollard 2013).

Collectively, these changes are thought to drive tumorigenesis in the multiple organ systems that demonstrate increased incidence of neoplasia in individuals harboring germline $S D H x$ mutations, which include paragangliomas/pheochromocytomas, GISTs and, among a subset, a histologically distinctive type of renal cell carcinoma (Gill et al. 2014, Williamson et al. 2015). Importantly, with regard to GISTs, SDH-deficient GISTs can be due to either genetic (SDHA, B, C or D mutations) or epigenetic (SDHC promoter methylation) changes. In principle, they can be either sporadic, due to somatic mutations within the tumor, or familial, related to germline mutations, though at present the vast majority are thought to be familial. In terms of classic descriptions of syndromal features, there are 2 distinctive but related syndromes that have SDH-deficient GISTs as a defining feature, Carney triad and CSS (Boikos et al. 2014, 2016a).

\section{Carney triad}

Carney triad was first described in 1977, as a triad of gastric leiomyosarcomas (now understood to be GISTs), paragangliomas and pulmonary chondromas (Carney et al. 1977). Carney triad has also been reported to be associated with esophageal leiomyoma and adrenal cortical adenoma; the overall course in affected individuals tends to be indolent (Carney 1999). The GISTs in Carney triad are essentially always gastric in location and tend to be multifocal, with epithelioid histology and a plexiform growth pattern (Chetty \& Serra 2016). In a report by the US NIH, it was shown that $95 \%$ of the affected patients are female, with a median age at presentation of 22 years (Zhang et al. 2010). In 2007, in a study of 37 patients with Carney triad, a 1q12-q21 deletion was identified as the most frequent and largest contiguous change, a region notably subtending the locus of the $S D H C$ gene (Matyakhina et al. 2007). However, $S D H x$ point mutations were not found at this time in affected individuals. For this reason, in 2011 it was proposed that patients with no SDHx mutations but with loss of SDHB by IHC should be considered as Carney triad patients (Gaal et al. 2011).

Later, studies revealed that at this same chromosomal locus 1q12-q21, patients with Carney triad had hypermethylation of the promoter of $S D H C$ and consequently reduced mRNA expression of $S D H C$, providing further evidence implicating this locus. Killian et al. then confirmed these results, performing genomewide DNA methylation profiling and demonstrating that six of the 15 Carney triad patients had SDHC epimutation (Haller et al. 2014, Killian et al. 2014). Finally, very recently, $S D H x$ mutations were found in patients with Carney triad, suggesting that the various SDH-deficient syndromes overlap significantly (Boikos et al. 2016b).

\section{Carney-Stratakis syndrome}

CSS was first described in 2002, as a syndrome of familial gastric GISTs and paragangliomas, which was described as separate from Carney triad (Carney \& Stratakis 2002). CSS is inherited as an autosomal-dominant syndrome with incomplete penetrance, such that affected patients may have either the complete CSS with GIST and paragangliomas or incomplete CSS with only GIST, being at risk to develop paragangliomas in the future. Patients are at risk, more rarely, also for other tumors such as renal 


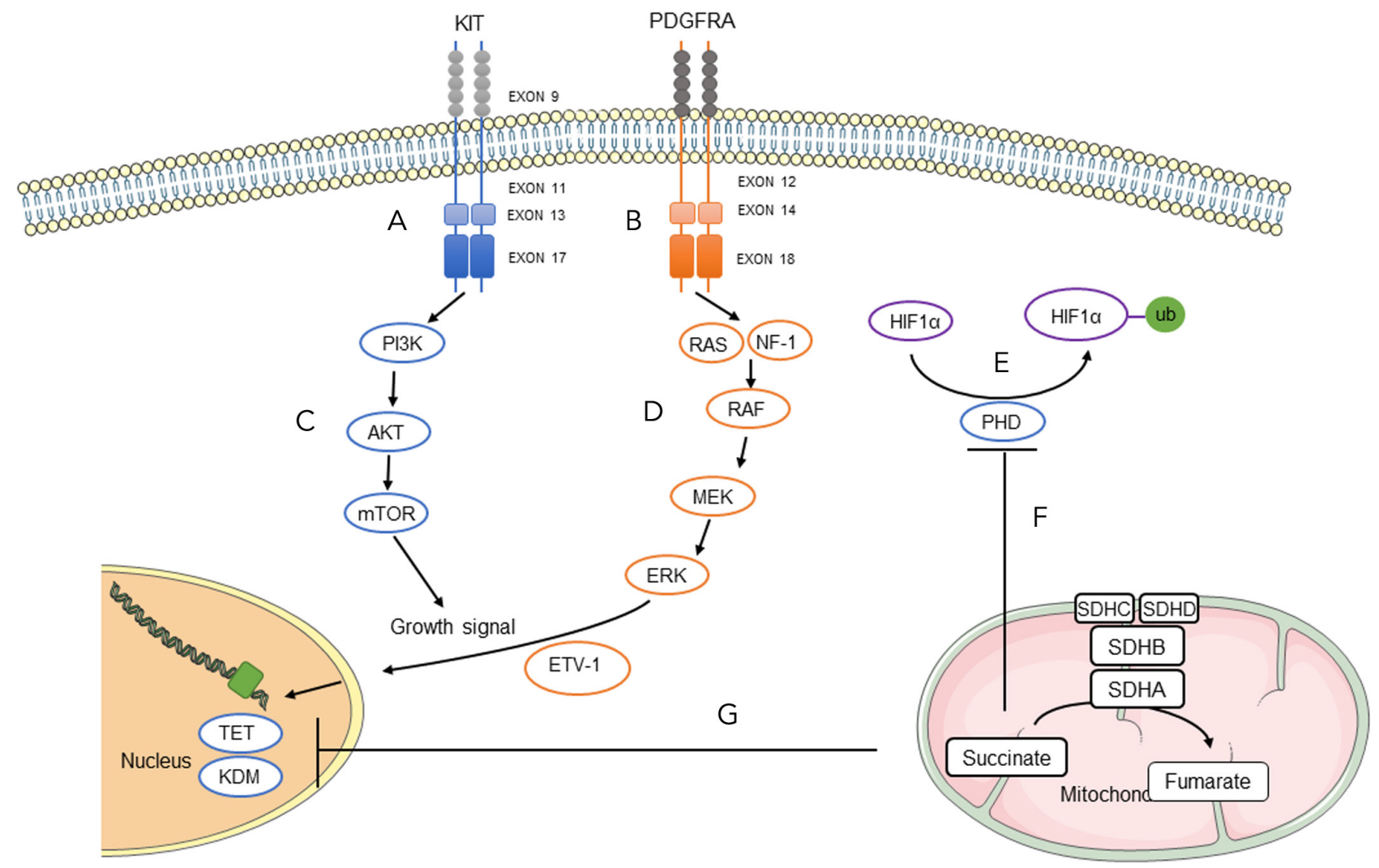

Figure 1

Oncogenic molecular pathways in gastrointestinal stromal tumor (GIST). (A) The most common mutations in KIT-mutated GIST are exon 11 (juxtamembrane domain), exon 9 (extracellular domain), exon 13 (ATP-binding pocket) and exon 17 (activation loop). (B) The most common mutations in PDGFRA-mutated GIST are exon 18 (activation loop), exon 12 (juxtamembrane domain) and exon 14 (auto-inhibitory part of juxtamembrane domain). (C) Mutation of KIT or PI3K leads to constitutive activation of PI3K-AKT-mTOR pathway, resulting in enhanced growth signaling. (D) Mutation of PDGFRA, NF1, BRAF or RAS leads to mobilization of RAS-RAF-MEK-ERK pathway. Together with ETV1, these signals cause induced activation of proliferation. (E) Under normoxic conditions, hypoxia-inducible factor (HIF) 1a undergoes degradation by prolyl-hydroxylase domain (PHD) proteinmediated hydroxylation via ubiquitination. (F) Succinate dehydrogenase (SDH) is a mitochondrial enzyme (heterotetrameric, complex II). Subunits A/B are catalytic proteins localized on mitochondrial inner membrane, and subunits $C / D$ are anchoring components. Inactivated mutation of these subunits causes accumulation of intracellular succinate, which competitively inhibits PHD proteins. Subsequent elevation of HIF-1a activity stimulates hypoxic signaling and associated tumorigenesis. (G) Succinate accumulation leads to inhibition of TET and KDM enzymes and global DNA and histone methylation changes, respectively.

cell carcinomas. These patients usually have a gastricbased multifocal GIST, epithelioid histology and median age in their third decade (Wada et al. 2016). In terms of the molecular pathogenesis of the syndrome, constitutional inactivating mutations of $S D H B, S D H C$ or $S D H D$ have been confirmed in the vast majority of CSS patients (Benn et al. 2006, McWhinney et al. 2007). Additionally, the syndrome of pituitary adenomas, paragangliomas and pheochromocytomas (3PAs) has also been reported to be associated with $S D H$ subunit germline mutations (Xekouki et al. 2015).

Notably, however, the SDH-deficient GISTs arising in these syndromes have been noted to have poor responses to traditional imatinib therapy (Pasini et al. 2008). This overall poor response rate is thought to relate to the lack of the activating tyrosine kinase mutations that drive

(c) 2018 Society for Endocrinology Published by Bioscientifica Ltd. Printed in Great Britain tumorigenesis as in SDH-competent (whether syndromal or sporadic) GISTs with KIT or PDGFRA mutations. Subgroup analysis of the EORTC phase III trial 62005 (imatinib in patients with unresectable/metastatic GISTs) reported that those with 'wild-type' (with respects to KIT and PDGFRA) GISTs (a group enriched for SDH-deficient GISTs) had a 76\% increased relative risk of death compared with patients with KIT exon 11 mutant GISTs (DebiecRychter et al. 2006).

Therefore, broader multitarget kinase inhibitors have emerged as future treatment candidates. Of note, in a human study of the SDH-deficient GIST subpopulations, the SDHA-mutated subset presented an impressively long survival with the use of sunitinib after imatinib (Pantaleo et al. 2015). In a phase I/II study which had included a total of 97 metastatic, imatinib-resistant GISTs, of which 
9 were wild-type GISTs, sunitinib was more active in KIT exon 9 mutant and wild-type GISTs than KIT exon 11 mutations (Heinrich et al. 2008). In the group of treatment failures after imatinib and sunitinib, administration of regorafenib showed significant activity, with median PFS of 12 months (George et al. 2012). Likewise, pazopanib demonstrated a potential response in heavily pretreated patients, though only five wild-type GIST patients were recruited in this phase II study (Ganjoo et al. 2014). In the adjuvant setting, subanalyses of wild-type GISTs in both the ACOSOG Z9001 trial (Corless et al. 2014) (32 patients) and the SSGXVIII (19 patients) (Joensuu et al. 2012) did not detect any benefit. A recent report from the NIH pediatric and wild-type GIST clinics further supports the contention that disease progression was largely dependent on tumor biology, regardless of location and resection margins. Most patients survive with disease progression, indicating that wild-type GIST is an overall indolent disease (Weldon et al. 2016). Additionally, particularly for SDH-competent syndromic GISTs with germline oncogenic mutations, at present there are no data to suggest that they should be treated any differently, with regard to adjuvant/neoadjuvant therapy, than their sporadic counterparts.

As many wild-type GISTs overexpress the IGF receptor 1, the SARC-022 phase 2 trial tested a new TKI, linsitinib, which results in significant inhibition of IGF receptor 1. Preliminary findings were not very promising, as no objective response could be observed. PFS at 9 months was 52\% (Mehren et al. 2014), though final reporting for this trial is still pending. There are currently 2 ongoing studies, specific for SDH-deficient tumors: one using the glutaminase inhibitor CB-839 (NCT 02071862) and another employing a new-generation DNA methyltransferase inhibitor, guadecitabine (SGI-110).

\section{Recommendations for familial/syndromic GISTs}

Patients with GIST and clinical features suggesting a type of syndromic/inherited GIST, as summarized in Table 1, should be offered an appropriate germline testing for the specific clinical phenotype. Once mutation is identified in any of the KIT/PDGFRA/SDH $A, B, C, D / N F 1$ genes, appropriate local and systemic treatment should be chosen, and genetic testing should be offered to firstdegree relatives.

There are no special surgical recommendations for familial KIT/PDGFRA/NF1-mutated GISTs, as distinct from sporadic GIST with such mutations. However, in contrast, patients with SDH-deficient GISTs tend to have limited benefit from an extensive or repeated surgery, since surgery in these patients has limited clinical benefit due to prevalent early metastases, the overall multifocal nature of the tumors and the nonetheless paradoxically indolent course of the disease. In a recent report from $\mathrm{NIH}$, presenting the follow-up data in a cohort of 76 patients, the 5- and 10-year event-free survival was 23.7 and $16.3 \%$, respectively (Weldon et al. 2016). Surgery in SDH-deficient GIST patients seems not to have a curative role, and the recommendation is that surgery should be considered primarily in the palliative setting, in cases of pain, obstruction or GI hemorrhage.

Postoperative surveillance with computed tomography scan or ${ }^{18} \mathrm{~F}$-FDG PET CT has been suggested

Table 1 Syndromic GIST.

\begin{tabular}{|c|c|c|c|c|c|}
\hline Type & Gene & Age & Sex & Pathology, site & Genetics \\
\hline $\begin{array}{l}\text { KIT-germline } \\
\text { mutation }\end{array}$ & $K I T$ exon $8,9,11,13,17$ & $40-50$ & N/A & $\begin{array}{l}\mathrm{S}>\mathrm{E} \text {, stomach/small } \\
\text { bowel }\end{array}$ & $\mathrm{AD} / \mathrm{HP}$ \\
\hline $\begin{array}{l}\text { PDGFRA germline } \\
\text { mutation }\end{array}$ & PDGFRA exon $12,14,18$ & $40-50$ & N/A & $\mathrm{M} / \mathrm{E}>\mathrm{S}$, stomach & $\mathrm{AD} / \mathrm{HP}$ \\
\hline NF type 1 & $N F-1$ & 49 & N/A & $\mathrm{S}>\mathrm{M}$, small bowel & $\begin{array}{l}\text { AD/HP, } \\
\text { variant } \\
\text { expression }\end{array}$ \\
\hline Carney's triad & $\begin{array}{l}\text { SDHC promoter } \\
\text { hypermethylation }\end{array}$ & $\sim 15$ & $\mathrm{~F}>\mathrm{M}$ & $\mathrm{E}>\mathrm{S}$, stomach & $\mathrm{N} / \mathrm{A}$ \\
\hline $\begin{array}{l}\text { Carney-Startakis } \\
\text { syndrome }\end{array}$ & $S D H_{x}$-mutation & $\sim 23$ & $\mathrm{~F}>\mathrm{M}$ & E>S, stomach & $A D / I P$ \\
\hline
\end{tabular}

\begin{tabular}{l} 
Features \\
\hline Various proliferation rate, ICC \\
hyperplasia/motility disorder, \\
skin pigmentation, \\
sporadically non-GIST tumors \\
Inflammatory fibroid polyp, \\
GI lipoma, no ICC \\
hyperplasia, large hands \\
observed \\
Café-au-lait spots, \\
neurofibroma, freckling, \\
paraganglioma, ICC \\
hyperplasia/motility disorder \\
Paraganglioma, pulmonary \\
chondroma, adrenal cortical \\
adenoma \\
Paraganglioma
\end{tabular}

$A D$, autosomal-dominant; E, epithelioid; HP, high penetrance; ICC, interstitial cell of Cajal; IP, incomplete penetration; $M$, mixed; S, spindle cell. 
previously every 3-6 months for surveillance of syndromic GIST. Patients with SDH-deficient GISTs, who have a more indolent course and are being diagnosed at a younger age, should be scanned primarily with MRI in order to minimize radiation exposure. Patients with SDH-deficient GISTs should also have annual wholebody MRI and urine or plasma catecholamines in order to detect paragangliomas. Other imaging modalities that have been used for paragangliomas are ${ }^{68} \mathrm{Ga}$-DOTATATE, 18F-DOPA and 18F-FDA (Ricci 2016). Similar modalities should be used for carriers with $S D H x$ mutations, since they are at risk to develop GIST or paragangliomas. Upper GI endoscopy with ultrasound and associated biopsy is important for biopsy and diagnosis but has a limited role for surveillance purposes.

The role of systemic treatment in various GIST syndromes has been discussed in previous sections of this review for each GIST syndrome, given the substantial differences between them. However, it is generally evident that imatinib has a very limited role in SDH-deficient GISTs, while in the other syndromes, the response to imatinib is variable, according to the specific genotype.

\section{Summary}

As the first solid tumor being treated by target therapy, the success in the past decade in treatment of GISTs is based on the growing understanding of its basic molecular biology. Though GISTs still represent a highly heterogeneous group of tumors, with much to learn in both their sporadic and syndromal/familial forms, the predictive and prognostic value of mutation status in this disease has become widely accepted as standard of care. Given that the genotype of each individual GIST has a substantial impact on treatment response, prognosis and drug resistance, the current translational goal is to provide ever more personalized regimens incorporating the mutational status of a GIST, key histologic and clinical staging factors and even such emerging data as secondary mutations. The concepts of leveraging high-throughput molecular data to propose combination therapies or structure/function analysis of individual mutations for novel target discovery are quickly becoming foreseeable, rather than just aspirational, goals on the horizon. Intriguingly, observations from these differing groups of familial and syndromic GISTs have confirmed in human kindreds the central importance of many of the driver mutations seen (and now targeted therapeutically) in the more common sporadic GISTs. We suspect that in the coming years, studies of the syndromic GISTs, especially the SDH-deficient group, will continue to drive forward the science and treatment of this disease.

\section{Declaration of interest}

The authors declare that there is no conflict of interest that could be perceived as prejudicing the impartiality of this review.

\section{Funding}

This research did not receive any specific grant from any funding agency in the public, commercial or not-for-profit sector.

\section{References}

Agarwal R \& Robson M 2009 Inherited predisposition to gastrointestinal stromal tumor. Hematology/Oncology Clinics of North America 23 1-13, vii. (https://doi.org/10.1016/j.hoc.2008.12.003)

Barnett CM, Corless CL \& Heinrich MC 2013 Gastrointestinal stromal tumors: molecular markers and genetic subtypes. Hematology/ Oncology Clinics of North America 27 871-888. (https://doi. org/10.1016/j.hoc.2013.07.003)

Bauer S, Duensing A, Demetri GD \& Fletcher JA 2007 KIT oncogenic signaling mechanisms in imatinib-resistant gastrointestinal stromal tumor: PI3-kinase/AKT is a crucial survival pathway. Oncogene 26 7560-7568. (https://doi.org/10.1038/sj.onc.1210558)

Benn DE, Gimenez-Roqueplo AP, Reilly JR, Bertherat J, Burgess J, Byth K, Croxson M, Dahia PL, Elston M, Gimm O, et al. 2006 Clinical presentation and penetrance of pheochromocytoma/paraganglioma syndromes. Journal of Clinical Endocrinology and Metabolism 91 827-836. (https://doi.org/10.1210/jc.2005-1862)

Boikos SA \& Stratakis CA 2014 The genetic landscape of gastrointestinal stromal tumor lacking KIT and PDGFRA mutations. Endocrine $\mathbf{4 7}$ 401-408. (https://doi.org/10.1007/s12020-014-0346-3)

Boikos SA, Helman LJ, Stratakis CA \& Pediatric and Wildtype GIST Clinic at the National Institutes of Health 2014 Thyroid hormone inactivation in gastrointestinal stromal tumors. New England Journal of Medicine 371 85-86. (https://doi.org/10.1056/NEJMc1405198)

Boikos SA, Pappo AS, Killian JK, LaQuaglia MP, Weldon CB, George S, Trent JC, von Mehren M, Wright JA, Schiffman JD, et al. $2016 a$ Molecular subtypes of KIT/PDGFRA wild-type gastrointestinal stromal tumors: a report from the National Institutes of Health Gastrointestinal Stromal Tumor Clinic. JAMA Oncology 2 922-928. (https://doi.org/10.1001/jamaoncol.2016.0256)

Boikos SA, Xekouki P, Fumagalli E, Faucz FR, Raygada M, Szarek E, Ball E, Kim SY, Miettinen M, Helman LJ, et al. 2016b Carney triad can be (rarely) associated with germline succinate dehydrogenase defects. European Journal of Human Genetics 24 569-573. (https://doi. org/10.1038/ejhg.2015.142)

Carney JA 1999 Gastric stromal sarcoma, pulmonary chondroma, and extra-adrenal paraganglioma (Carney Triad): natural history, adrenocortical component, and possible familial occurrence. Mayo Clinic Proceedings 74 543-552. (https://doi.org/10.4065/74.6.543)

Carney JA \& Stratakis CA 2002 Familial paraganglioma and gastric stromal sarcoma: a new syndrome distinct from the Carney triad. American Journal of Medical Genetics 108 132-139. (https://doi. org/10.1002/ajmg.10235)

Carney JA \& Stratakis CA 2008 Stromal, fibrous, and fatty gastrointestinal tumors in a patient with a PDGFRA gene mutation. American Journal of Surgical Pathology 32 1412-1420. (https://doi. org/10.1097/PAS.0b013e31816250ce)

Carney JA, Sheps SG, Go VL \& Gordon H 1977 The triad of gastric leiomyosarcoma, functioning extra-adrenal paraganglioma and 
pulmonary chondroma. New England Journal of Medicine 296 1517-1518. (https://doi.org/10.1056/NEJM197706302962609)

Chetty R \& Serra S 2016 Molecular and morphological correlation in gastrointestinal stromal tumours (GISTs): an update and primer. Journal of Clinical Pathology 69 754-760. (https://doi.org/10.1136/ jclinpath-2016-203807)

Chompret A, Kannengiesser C, Barrois M, Terrier P, Dahan P, Tursz T, Lenoir GM \& Bressac-De Paillerets B 2004 PDGFRA germline mutation in a family with multiple cases of gastrointestinal stromal tumor. Gastroenterology 126 318-321. (https://doi.org/10.1053/j. gastro.2003.10.079)

Corless CL, Schroeder A, Griffith D, Town A, McGreevey L, Harrell P, Shiraga S, Bainbridge T, Morich J \& Heinrich MC 2005 PDGFRA mutations in gastrointestinal stromal tumors: frequency, spectrum and in vitro sensitivity to imatinib. Journal of Clinical Oncology 23 5357-5364. (https://doi.org/10.1200/JCO.2005.14.068)

Corless CL, Barnett CM \& Heinrich MC 2011 Gastrointestinal stromal tumours: origin and molecular oncology. Nature Reviews Cancer 11 865-878. (https://doi.org/10.1038/nrc3143)

Corless CL, Ballman KV, Antonescu CR, Kolesnikova V, Maki RG Pisters PW, Blackstein ME, Blanke CD, Demetri GD, Heinrich MC, et al. 2014 Pathologic and molecular features correlate with long-term outcome after adjuvant therapy of resected primary GI stromal tumor: the ACOSOG Z9001 trial. Journal of Clinical Oncology 32 1563-1570. (https://doi.org/10.1200/JCO.2013.51.2046)

Debiec-Rychter M, Sciot R, Le Cesne A, Schlemmer M, Hohenberger P, van Oosterom AT, Blay JY, Leyvraz S, Stul M, Casali PG, et al. 2006 KIT mutations and dose selection for imatinib in patients with advanced gastrointestinal stromal tumours. European Journal of Cancer 42 1093-1103. (https://doi.org/10.1016/j. ejca.2006.01.030)

Demetri GD, von Mehren M, Blanke CD, Van den Abbeele AD, Eisenberg B, Roberts PJ, Heinrich MC, Tuveson DA, Singer S, Janicek M, et al. 2002 Efficacy and safety of imatinib mesylate in advanced gastrointestinal stromal tumors. New England Journal of Medicine 347 472-480. (https://doi.org/10.1056/NEJMoa020461)

Dibb NJ, Dilworth SM \& Mol CD 2004 Switching on kinases: oncogenic activation of BRAF and the PDGFR family. Nature Reviews Cancer 4 718-727. (https://doi.org/10.1038/nrc1434)

Forde PM, Cochran RL, Boikos SA, Zabransky DJ, Beaver JA, Meyer CF, Thornton KA, Montgomery EA, Lidor AO, Donehower RC, et al. 2016 Familial GI stromal tumor with loss of heterozygosity and amplification of mutant KIT. Journal of Clinical Oncology 34 e13-e16. (https://doi.org/10.1200/JCO.2013.51.6633)

Gaal J, Stratakis CA, Carney JA, Ball ER, Korpershoek E, Lodish MB, Levy I, Xekouki P, van Nederveen FH, den Bakker MA, et al. 2011 SDHB immunohistochemistry: a useful tool in the diagnosis of Carney-Stratakis and Carney triad gastrointestinal stromal tumors. Modern Pathology 24 147-151. (https://doi.org/10.1038/ modpathol.2010.185)

Ganjoo KN, Villalobos VM, Kamaya A, Fisher GA, Butrynski JE, Morgan JA, Wagner AJ, D'Adamo D, McMillan A, Demetri GD, et al. 2014 A multicenter phase II study of pazopanib in patients with advanced gastrointestinal stromal tumors (GIST) following failure of at least imatinib and sunitinib. Annals of Oncology 25 236-240. (https://doi.org/10.1093/annonc/mdt484)

George S, Wang Q, Heinrich MC, Corless CL, Zhu M, Butrynski JE, Morgan JA, Wagner AJ, Choy E, Tap WD, et al. 2012 Efficacy and safety of regorafenib in patients with metastatic and/or unresectable GI stromal tumor after failure of imatinib and sunitinib: a multicenter phase II trial. Journal of Clinical Oncology 30 2401-2407. (https://doi.org/10.1200/JCO.2011.39.9394)

Gill AJ 2012 Succinate dehydrogenase (SDH) and mitochondrial driven neoplasia. Pathology 44 285-292. (https://doi.org/10.1097/ PAT.0b013e3283539932)
Gill AJ, Benn DE, Chou A, Clarkson A, Muljono A, Meyer-Rochow GY, Richardson AL, Sidhu SB, Robinson BG \& Clifton-Bligh RJ 2010 Immunohistochemistry for SDHB triages genetic testing of SDHB, SDHC, and SDHD in paraganglioma-pheochromocytoma syndromes. Human Pathology 41 805-814. (https://doi.org/10.1016/j. humpath.2009.12.005)

Gill AJ, Hes O, Papathomas T, Sedivcova M, Tan PH, Agaimy A, Andresen PA, Kedziora A, Clarkson A, Toon CW, et al. 2014 Succinate dehydrogenase (SDH)-deficient renal carcinoma: a morphologically distinct entity: a clinicopathologic series of 36 tumors from 27 patients. American Journal of Surgical Pathology 38 1588-1602. (https://doi.org/10.1097/PAS.0000000000000292)

Haller F, Moskalev EA, Faucz FR, Barthelmess S, Wiemann S, Bieg M, Assie G, Bertherat J, Schaefer IM, Otto C, et al. 2014 Aberrant DNA hypermethylation of SDHC: a novel mechanism of tumor development in Carney triad. Endocrine-Related Cancer 21 567-577. (https://doi.org/10.1530/ERC-14-0254)

Heinrich MC, Griffith DJ, Druker BJ, Wait CL, Ott KA \& Zigler AJ 2000 Inhibition of c-kit receptor tyrosine kinase activity by STI 571, a selective tyrosine kinase inhibitor. Blood 96 925-932.

Heinrich MC, Corless CL, Demetri GD, Blanke CD, von Mehren M, Joensuu H, McGreevey LS, Chen CJ, Van den Abbeele AD, Druker BJ, et al. $2003 a$ Kinase mutations and imatinib response in patients with metastatic gastrointestinal stromal tumor. Journal of Clinical Oncology 21 4342-4349. (https://doi.org/10.1200/JCO.2003.04.190)

Heinrich MC, Corless CL, Duensing A, McGreevey L, Chen CJ, Joseph N, Singer S, Griffith DJ, Haley A, Town A, et al. 2003b PDGFRA activating mutations in gastrointestinal stromal tumors. Science 299 708-710. (https://doi.org/10.1126/science.1079666)

Heinrich MC, Maki RG, Corless CL, Antonescu CR, Harlow A, Griffith D, Town A, McKinley A, Ou WB, Fletcher JA, et al. 2008 Primary and secondary kinase genotypes correlate with the biological and clinical activity of sunitinib in imatinib-resistant gastrointestinal stromal tumor. Journal of Clinical Oncology 26 5352-5359. (https://doi. org/10.1200/JCO.2007.15.7461)

Heinrich MC, Griffith D, McKinley A, Patterson J, Presnell A, Ramachandran A \& Debiec-Rychter M 2012 Crenolanib inhibits the drug-resistant PDGFRA D842V mutation associated with imatinibresistant gastrointestinal stromal tumors. Clinical Cancer Research $\mathbf{1 8}$ 4375-4384. (https://doi.org/10.1158/1078-0432.CCR-12-0625)

Hirota S, Isozaki K, Moriyama Y, Hashimoto K, Nishida T, Ishiguro S, Kawano K, Hanada M, Kurata A, Takeda M, et al. 1998 Gain-offunction mutations of c-kit in human gastrointestinal stromal tumors. Science 279 577-580. (https://doi.org/10.1126/ science.279.5350.577)

Hirota S, Isozaki K, Nishida T \& Kitamura Y 2000 Effects of loss-offunction and gain-of-function mutations of c-kit on the gastrointestinal tract. Journal of Gastroenterology 35 (Supplement 12) 75-79. (https://doi.org/10.1007/PL00009983)

Hirota S, Ohashi A, Nishida T, Isozaki K, Kinoshita K, Shinomura Y \& Kitamura Y 2003 Gain-of-function mutations of platelet-derived growth factor receptor alpha gene in gastrointestinal stromal tumors. Gastroenterology 125 660-667. (https://doi.org/10.1016/S00165085(03)01046-1)

Jakhetiya A, Garg PK, Prakash G, Sharma J, Pandey R \& Pandey D 2016 Targeted therapy of gastrointestinal stromal tumours. World Journal of Gastrointestinal Surgery 8 345-352. (https://doi.org/10.4240/wjgs. v8.i5.345)

Joensuu H \& DeMatteo RP 2012 The management of gastrointestinal stromal tumors: a model for targeted and multidisciplinary therapy of malignancy. Annual Review of Medicine 63 247-258. (https://doi. org/10.1146/annurev-med-043010-091813)

Joensuu H, Roberts PJ, Sarlomo-Rikala M, Andersson LC, Tervahartiala P, Tuveson D, Silberman S, Capdeville R, Dimitrijevic S, Druker B, et al. 2001 Effect of the tyrosine kinase inhibitor STI571 in a patient with http://erc.endocrinology-journals.org https://doi.org/10.1530/ERC-17-0329
(2) 2018 Society for Endocrinology Published by Bioscientifica Ltd. Printed in Great Britain 
a metastatic gastrointestinal stromal tumor. New England Journal of Medicine 344 1052-1056. (https://doi.org/10.1056/ NEJM200104053441404)

Joensuu H, Eriksson M, Sundby Hall K, Hartmann JT, Pink D, Schutte J, Ramadori G, Hohenberger P, Duyster J, Al-Batran SE, et al. 2012 One vs three years of adjuvant imatinib for operable gastrointestinal stromal tumor: a randomized trial. JAMA $\mathbf{3 0 7} 1265-1272$. (https:// doi.org/10.1001/jama.2012.347)

Kalender M, Sevinc A, Tutar E, Sirikci A \& Camci C 2007 Effect of sunitinib on metastatic gastrointestinal stromal tumor in patients with neurofibromatosis type 1: a case report. World Journal of Gastroenterology 13 2629-2632. (https://doi.org/10.3748/wjg.v13. i18.2629)

Killian JK, Kim SY, Miettinen M, Smith C, Merino M, Tsokos M, Quezado M, Smith WI, Jahromi MS, Xekouki P, et al. 2013 Succinate dehydrogenase mutation underlies global epigenomic divergence in gastrointestinal stromal tumor. Cancer Discovery 3 648-657. (https:// doi.org/10.1158/2159-8290.CD-13-0092)

Killian JK, Miettinen M, Walker RL, Wang Y, Zhu YJ, Waterfall JJ, Noyes N, Retnakumar P, Yang Z, Smith WI, et al. 2014 Recurrent epimutation of SDHC in gastrointestinal stromal tumors. Science Translational Medicine 6 268ra177. (https://doi.org/10.1126/ scitranslmed.3009961)

Kindblom LG, Remotti HE, Aldenborg F \& Meis-Kindblom JM 1998 Gastrointestinal pacemaker cell tumor (GIPACT): gastrointestinal stromal tumors show phenotypic characteristics of the interstitial cells of Cajal. American Journal of Pathology 152 1259-1269.

Kleinbaum EP, Lazar AJ, Tamborini E, McAuliffe JC, Sylvestre PB, Sunnenberg TD, Strong L, Chen LL, Choi H, Benjamin RS, et al. 2008 Clinical, histopathologic, molecular and therapeutic findings in a large kindred with gastrointestinal stromal tumor. International Journal of Cancer 122 711-718. (https://doi.org/10.1002/ijc.23137)

Lee JL, Kim JY, Ryu MH, Kang HJ, Chang HM, Kim TW, Lee H, Park JH, Kim HC, Kim JS, et al. 2006 Response to imatinib in KIT- and PDGFRA-wild type gastrointestinal stromal associated with neurofibromatosis type 1. Digestive Diseases and Sciences $\mathbf{5 1}$ 1043-1046. (https://doi.org/10.1007/s10620-006-8003-1)

Li FP, Fletcher JA, Heinrich MC, Garber JE, Sallan SE, CurielLewandrowski C, Duensing A, van de Rijn M, Schnipper LE \& Demetri GD 2005 Familial gastrointestinal stromal tumor syndrome: phenotypic and molecular features in a kindred. Journal of Clinical Oncology 23 2735-2743. (https://doi.org/10.1200/JCO.2005.06.009)

Matyakhina L, Bei TA, McWhinney SR, Pasini B, Cameron S, Gunawan B, Stergiopoulos SG, Boikos S, Muchow M, Dutra A, et al. 2007 Genetics of carney triad: recurrent losses at chromosome 1 but lack of germline mutations in genes associated with paragangliomas and gastrointestinal stromal tumors. Journal of Clinical Endocrinology and Metabolism 92 2938-2943. (https://doi.org/10.1210/jc.20070797)

McWhinney SR, Pasini B, Stratakis CA \& International Carney Triad and Carney-Stratakis Syndrome Consortium 2007 Familial gastrointestinal stromal tumors and germ-line mutations. New England Journal of Medicine 357 1054-1056. (https://doi.org/10.1056/ NEJMc071191)

von Mehren M, George S, Heinrich MC, Schuetze S, Belinsky MG, Janeway KA, Rink L, Ganjoo KN, Yu JQ, Yap JT, et al. 2014 Results of SARC 022, a phase II multicenter study of linsitinib in pediatric and adult wild-type (WT) gastrointestinal stromal tumors (GIST). Journal of Clinical Oncology 32 (15 Supplement) abstract 10507. (https://doi. org/10.1200/jco.2014.32.15_suppl.10507)

Miettinen M, Fetsch JF, Sobin LH \& Lasota J 2006 Gastrointestinal stromal tumors in patients with neurofibromatosis 1: a clinicopathologic and molecular genetic study of 45 cases. American Journal of Surgical Pathology 30 90-96. (https://doi.org/10.1097/01. pas.0000176433.81079.bd)
Mussi C, Schildhaus HU, Gronchi A, Wardelmann E \& Hohenberger P 2008 Therapeutic consequences from molecular biology for gastrointestinal stromal tumor patients affected by neurofibromatosis type 1. Clinical Cancer Research 14 4550-4555. (https://doi. org/10.1158/1078-0432.CCR-08-0086)

Pantaleo MA, Lolli C, Nannini M, Astolfi A, Indio V, Saponara M, Urbini M, La Rovere S, Gill A, Goldstein D, et al. 2015 Good survival outcome of metastatic SDH-deficient gastrointestinal stromal tumors harboring SDHA mutations. Genetics in Medicine 17 391-395. (https://doi.org/10.1038/gim.2014.115)

Pasini B, Matyakhina L, Bei T, Muchow M, Boikos S, Ferrando B, Carney JA \& Stratakis CA 2007 Multiple gastrointestinal stromal and other tumors caused by platelet-derived growth factor receptor alpha gene mutations: a case associated with a germline V561D defect. Journal of Clinical Endocrinology and Metabolism 92 3728-3732. (https://doi.org/10.1210/jc.2007-0894)

Pasini B, McWhinney SR, Bei T, Matyakhina L, Stergiopoulos S, Muchow M, Boikos SA, Ferrando B, Pacak K, Assie G, et al. 2008 Clinical and molecular genetics of patients with the Carney-Stratakis syndrome and germline mutations of the genes coding for the succinate dehydrogenase subunits SDHB, SDHC, and SDHD. European Journal of Human Genetics 16 79-88. (https://doi.org/10.1038/sj. ejhg.5201904)

Ricci R 2016 Syndromic gastrointestinal stromal tumors. Hereditary Cancer in Clinical Practice 14 15. (https://doi.org/10.1186/s13053-0160055-4)

Ricci R, Martini M, Cenci T, Carbone A, Lanza P, Biondi A, Rindi G, Cassano A, Larghi A, Persiani R, et al. 2015 PDGFRA-mutant syndrome. Modern Pathology 28 954-964. (https://doi.org/10.1038/ modpathol.2015.56)

Schroeder B, Li Z, Cranmer LD, Jones RL \& Pollack SM 2016 Targeting gastrointestinal stromal tumors: the role of regorafenib. OncoTargets and Therapy 9 3009-3016. (https://doi.org/10.2147/OTT.S104081)

Soreide K, Sandvik OM, Soreide JA, Giljaca V, Jureckova A \& Bulusu VR 2016 Global epidemiology of gastrointestinal stromal tumours (GIST): a systematic review of population-based cohort studies. Cancer Epidemiology 40 39-46. (https://doi.org/10.1016/j. canep.2015.10.031)

Wada R, Arai H, Kure S, Peng WX \& Naito Z 2016 'Wild type' GIST: clinicopathological features and clinical practice. Pathology International 66 431-437. (https://doi.org/10.1111/pin.12431)

Wang JH, Lasota J \& Miettinen M 2011 Succinate dehydrogenase subunit B (SDHB) is expressed in neurofibromatosis 1-associated gastrointestinal stromal tumors (gists): implications for the SDHB expression based classification of gists. Journal of Cancer 2 90-93. (https://doi.org/10.7150/jca.2.90)

Wang YM, Gu ML \& Ji F 2015 Succinate dehydrogenase-deficient gastrointestinal stromal tumors. World Journal of Gastroenterology 21 2303-2314. (https://doi.org/10.3748/wjg.v21.i8.2303)

Weldon CB, Madenci AL, Boikos SA, Janeway KA, George S, von Mehren M, Pappo AS, Schiffman JD, Wright J, Trent JC, et al. 2016 Surgical management of wild-type gastrointestinal stromal tumors: a report from the National Institutes of Health Pediatric and Wildtype GIST Clinic. Journal of Clinical Oncology 35 523-528. (https://doi. org/10.1200/jco.2016.68.6733)

Williamson SR, Eble JN, Amin MB, Gupta NS, Smith SC, Sholl LM, Montironi R, Hirsch MS \& Hornick JL 2015 Succinate dehydrogenase-deficient renal cell carcinoma: detailed characterization of 11 tumors defining a unique subtype of renal cell carcinoma. Modern Pathology 28 80-94. (https://doi.org/10.1038/ modpathol.2014.86)

Xekouki P, Szarek E, Bullova P, Giubellino A, Quezado M, Mastroyannis SA, Mastorakos P, Wassif CA, Raygada M, Rentia N, et al. 2015 Pituitary adenoma with paraganglioma/pheochromocytoma (3PAs) and succinate dehydrogenase defects in humans and mice. http://erc.endocrinology-journals.org https://doi.org/10.1530/ERC-17-0329
C) 2018 Society for Endocrinology Published by Bioscientifica Ltd. Printed in Great Britain 
Journal of Clinical Endocrinology and Metabolism 100 E710-E719. (https://doi.org/10.1210/jc.2014-4297)

Yang M \& Pollard PJ 2013 Succinate: a new epigenetic hacker. Cancer Cell 23 709-711. (https://doi.org/10.1016/j.ccr.2013.05.015)

Zhang L, Smyrk TC, Young WF Jr, Stratakis CA \& Carney JA 2010 Gastric stromal tumors in Carney triad are different clinically, pathologically, and behaviorally from sporadic gastric gastrointestinal stromal tumors: findings in 104 cases. American Journal of Surgical Pathology 34 53-64. (https://doi.org/10.1097/PAS.0b013e3181c20f4f)

Zoller ME, Rembeck B, Oden A, Samuelsson M \& Angervall L 1997

Malignant and benign tumors in patients with neurofibromatosis type 1 in a defined Swedish population. Cancer 79 2125-2131. (https://doi.org/10.1002/(SICI)1097-0142(19970601)79:11<2125::AIDCNCR9>3.0.CO;2-N)

Received in final form 21 November 2017

Accepted 23 November 2017

Accepted Preprint published online 23 November 2017
C 2018 Society for Endocrinology Published by Bioscientifica Ltd. 